\title{
Pengaruh Komponen Risk Based Bank Rating Pada Nilai Perusahaan Perbankan
}

\author{
Ketut Krisna Savitri ${ }^{1}$ \\ Fakultas Ekonomi dan Bisnis \\ Universitas Udayana, Indonesia. \\ Email: savitrikrisna4@gmail.com
}

\author{
I Wayan Ramantha ${ }^{2}$ \\ Fakultas Ekonomi dan Bisnis \\ Universitas Udayana, Indonesia.
}

\begin{abstract}
ABSTRAK
Penelitian ini bertujuan untuk menguji secara empiris pengaruh komponen risk based bank rating yang diukur dengan non performing loan, loan to deposit ratio, good corporate governance, return on assets dan capital adequacy ratio pada nilai perusahaan perbankan yang terdaftar di Bursa Efek Indonesia (BEI) Tahun 2013-2017. Sampel penelitian dipilih menggunakan metode nonprobability sampling dengan teknik purposive sampling dan diperoleh sebanyak 6 perusahaan perbankan, sehingga jumlah pengamatan dengan periode penelitian selama 5 tahun adalah 30 amatan. Teknik analisis data yang digunakan adalah analisis regresi linear berganda. Hasil penelitian ini menunjukkan bahwa non performing loan dan loan to deposit ratio berpengaruh negatif pada nilai perusahaan perbankan. Return on assets dan capital adequacy ratio berpengaruh positif pada nilai perusahaan perbankan dan good corporate governance tidak berpengaruh pada. nilai perusahaan perbankan.
\end{abstract}

Kata Kunci: Risk Based Bank Rating; Nilai Perusahaan; Perbankan.

\section{The Effects of Risk Based Bank Rating Components on Banking Company Value}

\begin{abstract}
This study aims to empirically examine the effect of the risk-based bank rating component as measured by non-performing loans, loan to deposit ratio, good corporate governance, return on assets and capital adequacy ratio on the value of banking companies listed on the Indonesia Stock Exchange (BEI) Year 2013-2017. The research sample was selected using the nonprobability sampling method with a purposive sampling technique and obtained as many as 6 banking companies, so that the number of observations with a study period of 5 years was 30 observations. The data analysis technique used is multiple linear regression analysis. The results of this study indicate that non-performing loans and loan to deposit ratios have a negative effect on the value of banking companies. Return on assets and capital adequacy ratio have a positive effect on the value of banking companies and good corporate governance does not affect the value of banking companies.
\end{abstract}

Keywords : $\quad$ Risk Based Bank Rating; Company Value; Banking.

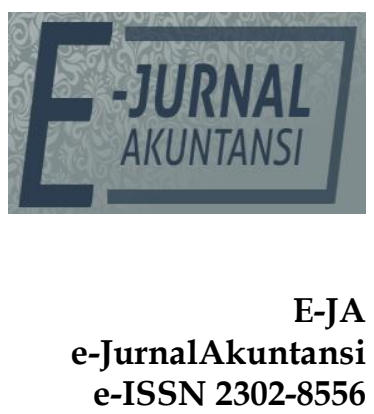

Vol. 29 No. 2

Denpasar, November

2019

Hal. 883-898

Artikel masuk:

09 Oktober 2019

Tanggal diterima:

17 November 2019 


\section{PENDAHULUAN}

Nilai perusahaan adalah gambaran mengenai keadaan umum suatu perusahaan. Nilai perusahaan dapat dijadikan sebagai pertimbangan bagi para investor sebelum memutuskan untuk melakukan investasi. Pada umumnya investor cenderung percaya terhadap prospek perusahaan apabila perusahaan memiliki nilai perusahaan yang tinggi. Nilai perusahaan dapat dilihat dari harga saham perusahaan (Fama, 1978). Perusahaan yang memiliki harga saham tinggi menunjukkan bahwa perusahaan tersebut mampu dalam segi keuangan dan menunjukkan kepada investor bahwa perusahaan dapat memberikan pengembalian investasi yang memadai (Wahyuni, 2018). Nilai perusahaan pada penelitian ini diukur dengan Price to Book Value (PBV). Price to Book Value (PBV) merupakan rasio dari harga per saham dibagi nilai buku per saham (Ross et al., 2016:66). Gambar 1. menyajikan rata-rata nilai perusahaan sektor perbankan yang tercatat di Bursa Efek Indonesia Tahun 2013 sampai Tahun 2017 yang diukur dengan PBV.

Nilai Perusahaan Perbankan Tahun 2013-2017

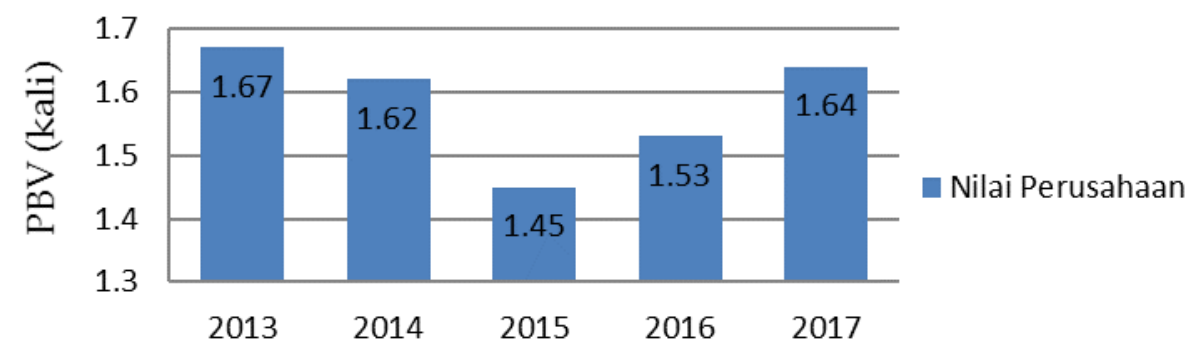

Gambar 1. Rata-rata Nilai Perusahaan Perbankan Tahun 2013-2017

Sumber: Data Penelitian, 2019

Berdasarkan Gambar 1. dapat dilihat bahwa pada tahun 2014 dan 2015 terjadi penurunan nilai perusahaan pada sektor perbankan yang terdaftar di BEI. Pada tahun 2015 terjadi penurunan nilai perusahaan sektor perbankan yang sangat signifikan yaitu sebesar 0,17 dari tahun 2014, sebelumnya di tahun 2014 nilai perusahaan perbankan sebesar 1,62 kemudian turun menjadi 1,45 di Tahun 2015. Hal yang berbeda terjadi pada tahun 2016 dan 2017 nilai perusahaan perbankan mengalami peningkatan secara berturut-turut sebesar 0,08 di tahun 2016 dan sebesar 0,11 di tahun 2017. Berdasarkan fenomena naik turunnya nilai perusahaan perbankan tersebut memotivasi peneliti untuk melakukan penelitian terhadap nilai perusahaan khususnya pada sektor perbankan.

Berdasarkan Gambar 1. fenomena penurunan nilai perusahaan sektor perbankan di tahun 2014 sampai tahun 2015 dipicu oleh berbagai faktor, salah satunya adalah tingkat kesehatan bank. Penilaian terhadap tingkat kesehatan bank mampu menjadi suatu sinyal bagi para investor dalam membuat keputusan berinvestasi (Anggarsini dan Suprasto, 2018). Kondisi kesehatan bank yang baik dapat menarik minat dan kepercayaan yang timbul terhadap bank baik dari pihak internal ataupun pihak eksternal (Maheswari dan Suryanawa, 2016). Tingkat kesehatan suatu bank yang baik akan direspon oleh investor melalui peningkatan pada harga saham sehingga berdampak terhadap meningkatnya nilai perusahaan. Penilaian tingkat kesehatan bank secara umum diatur dalam 
Surat Edaran Otoritas Jasa Keuangan Nomor 14/SEOJK.03/2017 yang merupakan petunjuk pelaksanaan dari Peraturan Otoritas Jasa Keuangan Nomor 4/POJK.03/2016 mengenai penilaian tingkat kesehatan bank umum, yang mewajibkan bank umum untuk melakukan penilaian sendiri (self assessment) dengan menggunakan pendekatan risiko (Risk Based Bank Rating/RBBR). Risk based bank rating adalah penilaian tingkat kesehatan bank berdasarkan risiko. Penilaian risk based bank rating dilakukan terhadap empat faktor yaitu risk profile, good corporate governance (GCG), earnings, dan capital.

Berdasarkan Surat Edaran OJK No. 14/SEOJK.03/2017 risk profile adalah risiko yang dimiliki oleh bank dalam menjalankan kegiatan operasionalnya. Penilaian terhadap risk profile merupakan penilaian terhadap risiko inheren dan kualitas penerapan manajemen risiko dalam operasional bank yang terdiri dari delapan risiko, namun dalam penelitian ini hanya menggunakan dua risiko yaitu risiko kredit dan risiko likuiditas sebagai proksi untuk mengukur risk profile, hal ini karena dua faktor risiko tersebut dapat dihitung secara kuantitatif serta memiliki kriteria pemeringkatan yang jelas. Selain itu, risiko kredit dan risiko likuiditas sangat berhubungan dengan kebangkrutan suatu bank (Fitriyanto, 2018). Risiko kredit adalah salah satu risiko yang paling signifikan dihadapi oleh bank, mengingat pemberian kredit merupakan sumber pendapatan utama bank (Alshatti, 2015). Risiko likuiditas bank berkaitan dengan kemampuan bank dalam menyediakan dana yang dapat ditarik sewaktu-waktu oleh para deposan.

Pada penelitian ini risiko kredit diukur dengan rasio Non Performing Loan (NPL). Semakin rendah risiko kredit, maka kemungkinan bank mengalami kerugian sangat rendah, hal ini tentu akan meningkatkan kepercayaan investor terhadap prospek perusahaan kedepannya sehingga dapat meningkatkan nilai perusahaan. Hasil penelitian Hidayat (2014) serta Nugroho dan Kusumawati (2017) menemukan bahwa risiko kredit yang diukur dengan NPL memiliki pengaruh negatif terhadap nilai perusahaan. Sedangkan hasil penelitian Wardoyo dan Agustini (2015) serta Irianti dan Saifi (2017) menemukan bahwa risiko kredit tidak memiliki pengaruh padat nilai perusahaan. Risiko likuiditas dapat dilihat melalui besarnya loan to deposit ratio (LDR) yang dimiliki oleh bank. Tingginya nilai LDR akibat adanya peningkatan dalam penyaluran kredit akan berdampak terhadap rendahnya likuiditas yang dimiliki oleh bank yang berpengaruh terhadap penurunan tingkat kepercayaan pihak eksternal perusahaan yang sehingga mengakibatkan penurunan nilai perusahaan. Hasil penelitian Yuliati dan Zakaria (2016) menemukan bahwa LDR berpengaruh negatif pada nilai perusahaan. Akan tetapi hasil penelitian Putra dan Suardikha (2018) menemukan LDR berpengaruh positif pada nilai perusahaan.

Nilai perusahaan yang baik juga dapat dicerminkan dari tata kelola perusahaan yang baik. Forum for Corporate Governance in Indonesia - FCGI (2001) mengartikan good corporate governance (GCG) sebagai seperangkat peraturan yang mengatur hubungan antara manajer, pemegang saham, pemerintah, kreditur, staf, serta pihak lain yang memiliki kepentingan dalam suatu perusahaan yang berkaitan dengan hak dan kewajiban mereka, GCG juga dapat didefinisikan sebagai suatu mekanisme yang mampu mengatur sekaligus mengendalikan suatu perusahaan. Perusahaan yang menerapkan praktik GCG umumnya dapat lebih diminati oleh para investor karena dalam jangka waktu yang panjang 
perusahaan akan lebih menguntungkan serta lebih kompetitif daripada perusahaan yang memiliki tata kelola perusahaan yang buruk (Todorovic, 2013). Hal ini tentu akan meningkatkan keyakinan investor untuk berinvestasi pada perusahaan tersebut sehingga nilai perusahaan akan meningkat. Penelitian Johnson et al., (2000), Anggarsini dan Suprasto (2018) dan Lestari dan Wirakusuma, (2018) menemukan GCG memiliki pengaruh positif pada nilai perusahaan. Berbeda dengan hasil penelitian Sitorus et al., (2013), Fitri dan Herwiyanti (2015) dan Fatchan dan Trisnawati (2016) menemukan GCG tidak berpengaruh pada nilai perusahaan.

Penilaian earnings digunakan untuk mengetahui kemampuan bank dalam menghasilkan laba selama periode tertentu (Dewi dan Yadnyana, 2019). Earnings pada penelitian ini diukur menggunakan Return on Assets (ROA). Return on asset menunjukan efisiensi manajemen dalam menggunakan aset yang dimiliki perusahaan untuk meningkatkan keuntungan (Muhammad dan Scrimgeour, 2014). Perusahaan perbankan yang memiliki nilai ROA yang tinggi, cenderung lebih diminati oleh para investor karena dengan meningkatnya laba yang mampu dihasilkan dalam satu periode menunjukkan kemampuan bank dalam mengelola aset perusahaan secara optimal serta menunjukkan bank memiliki prospek yang baik dimasa mendatang, hal inilah yang menjadi daya tarik dari perusahaan tersebut sehingga investor bersedia melakukan investasi pada perusahaan tersebut sehingga dapat meningkatkan nilai perusahaan. Penelitian Hidayat (2014), Indasari dan Yadnyana (2018) dan Irianti dan Saifi (2017) menemukan earnings memiliki pengaruh positif pada nilai perusahaan. Berbeda dengan penelitian yang dilakukan oleh Moniaga (2013) menemukan bahwa ROA tidak memiliki pengaruh pada nilai perusahaan.

Kecukupan modal (capital) mengacu pada jumlah modal ekuitas dan surat berharga lainnya yang dimiliki bank sebagai cadangan terhadap aset berisiko guna melindungi bank terhadap kemungkinan kegagalan bank (Agbeja et al., 2015). Kecukupan modal (capital) yang dimiliki bank dalam penelitian ini diukur dengan Capital Adequacy Ratio (CAR). Tingkat kecukupan modal yang dimiliki oleh perusahaan mampu menjaga kepercayaan pihak eksternal pada kinerja suatu bank (Putri dan Dana, 2018). Penelitian Hidayat (2014), Lestari dan Wirakusuma (2018) dan Anggarsini dan Suprasto (2018) menunjukkan capital memiliki pengaruh positif padai nilai perusahaan. Berbeda dengan hasil penelitian Wardoyo dan Agustini (2015), Irianti dan Saifi (2017) serta Nugroho dan Kusumawati (2017) menemukan capital yang diukur dengan CAR tidak memiliki pengaruh pada nilai perusahaan.

Penelitian ini dilakukan pada perusahaan perbankan yang terdaftar di Bursa Efek Indonesia (BEI), pengambilan objek ini didasari karena siklus hidup bank yang mengandalkan tingkat kepercayaan dari masyarakat karena hampir seluruh modal dan operasional bank berhubungan dengan masyarakat. Oleh karena itu, bank harus menerapkan prinsip kehati-hatian dalam beroperasional dan menjaga tingkat kesehatan bank serta menjaga nilai perusahaannya. Penelitian ini dilakukan untuk mengetahui konsistensi hasil penelitian terdahulu dengan penelitian sekarang dengan fenomena yang berbeda dan juga periode waktu yang berbeda. 
Teori sinyal merupakan grand theory dalam penelitian ini. Menurut Spence (1973) pihak perusahaan berusaha memberikan suatu sinyal dalam bentuk informasi relevan kepada pihak eksternal perusahaan, kemudian pihak eksternal akan menyelaraskan perilaku serta identifikasinya terhadap sinyal yang disampaikan. Teori sinyal menggambarkan hubungan antara komponen risk based bank rating dengan nilai perusahaan sektor perbankan, penilaian komponen risk based bank rating pada perusahaan perbankan dapat menjadi informasi bagi para investor untuk menganalisa kinerja perbankan yang berguna dalam membuat keputusan berinvestasinya.

Risiko perbankan yang rendah dapat menjadi sinyal bagi investor bahwa manajemen telah mampu mengatasi serta meminimalkan resiko inheren dalam perbankan. Penilaian risk profile pada penelitian ini menggunakan risiko kredit. Risiko kredit dapat dilihat dari nilai non performing loan (NPL) suatu bank. Tingginya risiko kredit yang tinggi tercermin dari rasio NPL bank yang tinggi, hal tersebut menunjukkan kemungkinan bank akan mengalami kerugian hal ini dikarenakan dana yang semestinya diterima oleh pihak bank harus tertahan di pihak debitur, hal ini mengakibatkan terbatasnya dana operasional yang dimiliki oleh bank sehingga akan mengakibatkan menurunnya laba yang dihasilkan dan akan berdampak terhadap menurunnya nilai perusahaan (Anggarsini dan Suprasto, 2018). Pernyataan ini didukung dengan hasil penelitian Hidayat (2014) serta Nugroho dan Kusumawati (2017) menemukan bahwa NPL memiliki pengaruh negatif pada nilai perusahaan. Berdasarkan uraian diatas, maka hipotesis yang diajukan adalah sebagai berikut:

$\mathrm{H}_{1}$ : Non Performing Loan (NPL) berpegaruh negatif pada nilai perusahaan.

Penilaian risk profile juga menggunakan risiko likuiditas. Rendahnya risiko likuiditas yang dimiliki oleh bank menjadi sinyal bagi investor bahwa bank memiliki likuiditas yang tinggi dalam memenuhi kewajibannya kepada para deposan. Loan to Deposit Ratio (LDR) merupakan rasio yang dapat menggambarkan risiko likuiditas bank. Tingginya nilai LDR akan menurunkan persentase cadangan likuiditas yang berdampak pada ketidakmampuan bank dalam menyediakan dana yang dapat ditarik sewaktu-waktu oleh para deposan, hal ini mengurangi kepercayaan investor ataupun masyarakat terhadap perusahaan perbankan sehingga dapat menurunkan nilai perusahaan. Pernyataan ini didukung oleh penelitian Yuliati dan Zakaria (2016) yang menemukan bahwa LDR berpengaruh negatif pada nilai perusahaan. Berdasarkan uraian diatas, maka hipotesis yang diajukan adalah sebagai berikut. $\mathrm{H}_{2}$ : Loan to Deposit Ratio (LDR) berpengaruh negatif pada nilai perusahaan.

Perusahaan yang menerapkan good corporate governance (GCG) dapat menjadi sinyal bagi pihak eksternal bahwa perusahaan sudah melaksanakan pengelolaan manajemen yang baik. Menurut Putra (2014) nilai perusahaan dapat meningkat dengan penerapan GCG. Menurut Jensen dan Meckling (1976) teori agensi yang menjelaskan adanya hubungan yang bersifat kontraktual antara principal dengan agen. Berdasarkan teori agensi, GCG merupakan respon perusahaan terhadap konflik keagenan yang terjadi di suatu perusahaan, karena dengan adanya pengawasan mekanisme tata kelola perusahaan yang baik, dianggap mampu mengurangi masalah keagenan (Wijaya dan Wirawati, 2019). Rendahnya tingkat masalah keagenan yang terjadi pada suatu perusahaan 
menunjukkan bahwa perusahaan memiliki tata kelola perusahaan yang baik, hal ini tentu akan menjadi daya tarik bagi investor sehingga akan meningkatkan nilai perusahaan. Pernyataan ini didukung oleh penelitian Gherghina (2015), Lestari dan Wirakusuma (2018) serta Anggarsini dan Suprasto (2018) juga menemukan bahwa good corporate governance memiliki pengaruh positif pada nilai perusahaan. Berdasarkan uraian diatas, maka hipotesis yang diajukan adalah sebagai berikut.

$\mathrm{H}_{3}$ : Good Corporate Governance (GCG) berpengaruh positif pada nilai perusahaan.

Informasi earnings yang diungkapkan di laporan keuangan merupakan sinyal positif bagi para investor yang menunjukkan kemampuan suatu perusahaan menghasilkan laba dalam satu periode. Earnings pada penelitian ini diukur dengan return on assets (ROA). Besarnya laba yang dihasilkan suatu perusahaan menunjukkan perusahaan sanggup mengelola asset perusahaan dengan optimal sehingga mampu menghasilkan laba yang tinggi dalam satu periode. Hal ini tentunya dapat meningkatkani keyakinan investor untuk menanamkan modalnya pada perusahaan tersebut sehingga akan berdampak terhadap peningkatan nilai perusahaan. Pernyataan ini didukung oleh penelitian sebelumnya yaitu Hidayat (2014), Asiri dan Hameed (2014) serta Lestari dan Wirakusuma (2018) yang menemukan bahwa Return On Assets (ROA) berpengaruh positif pada nilai perusahaan. Berdasarkan uraian di atas, maka hipotesis yang diajukan adalah sebagai berikut.

$\mathrm{H}_{4}$ : Return on Assets (ROA) berpengaruh positif pada nilai perusahaan.

Penilaian terhadap capital (permodalan) juga merupakan sinyal kepada pihak eksternal yang menunjukkan perusahaan dapat mengelola modalnya secara optimal sehingga mampu mencukupi kebutuhan permodalannya (Anggarsini dan Suprasto, 2018). Penilaian kecukupan modal (capital) yang dimiliki oleh bank menggunakan Capital Adequacy Ratio (CAR). Semakin meningkatnya nilai CAR, menandakan semakin baik pula pembiayaan atas aktiva berisiko (kredit, penyertaan surat berharga, tagihan pada bank lain) yang dimiliki bank sehingga dapat mengurangi kemungkinan adanya kebangkrutan. Hal ini menunjukkan prospek bank yang baik di masa mendatang sehingga bank memperoleh kepercayaan dan mampu meningkatkan keyakinan investor untuk melakukan investasi pada perusahaan tersebut sehingga berdampak terhadap meningkatnya nilai perusahaan. Pernyataan ini didukung oleh hasil penelitian sebelumnya yaitu Chowdhury dan Chowdhury (2010), Hermuningsih (2013), Anggarsini dan Suprasto (2018) serta Lestari dan Wirakusuma (2018) yang menemukan bahwa Capital Adequacy Ratio (CAR) berpengaruh positif pada nilai perusahaan. Berdasarkan uraian diatas, maka hipotesis yang diajukan adalah sebagai berikut.

$\mathrm{H}_{5}$ : Capital Adequacy Ratio (CAR) berpengaruh positif pada nilai perusahaan.

\section{METODE PENELITIAN}

Penelitian ini menggunakan pendekatan kuantitatif berbentuk asosiaif tipe kausalitas. Penelitian ini dilakukan pada perusahaan sektor perbankan yang tercatat di Bursa Efek Indonesia (BEI) Tahun 2013-2017. Objek dari penelitian ini adalah nilai perusahaan perbankan yang terdaftar di BEI periode 2013-2017 dengan risiko kredit, risiko likuiditas, GCG, earnings dan capital sebagai variabel 
independen. Variabel terikat dalam penelitian ini adalah nilai perusahaan perbankan $(\mathrm{Y})$, sedangkan variabel bebas dalam penelitian ini adalah non performing loan $\left(\mathrm{X}_{1}\right)$, loan to deposit ratio $\left(\mathrm{X}_{2}\right)$, good corporate governance $\left(\mathrm{X}_{3}\right)$, return on assets $\left(\mathrm{X}_{4}\right)$ dan capital adequecy ratio $\left(\mathrm{X}_{5}\right)$.

Nilai perusahaan merupakan harga yang bersedia dibayar oleh calon pembeli apabila perusahaan tersebut dijual. Nilai perusahaan dalam penelitian ini diukur menggunakan Price to Book Value (PBV). Rumus Price to Book Value (PBV) yang digunakan adalah sebagai berikut (Weston dan Copeland, 1997).

$$
\text { PBV }=\frac{\text { Harga Saham }}{\text { BookValue per Sharg }} \text {. }
$$

Risiko kredit diukur dengan rasio Non Performing Loan (NPL). NPL merupakan persentase jumlah kredit bermasalah (dengan kriteria kurang lancar, diragukan, dan macet) terhadap total kredit yang disalurkan (Maheswari dan Suryanawa, 2016). Menurut Surat Edaran OJK No. 14/SEOJK.03/2017 NPL dapat dihitung menggunakan rumus sebagai berikut:

$$
\text { NPL }=\frac{\text { KreditBermasalah }}{\text { Total Kredit }} \times 100 \%
$$

Risiko likuiditas diukur menggunakan rasio Loan to Deposit Ratio (LDR). Loan to Deposit Ratio adalah rasio yang digunakan untuk mengukur total kredit (kredit yang diberikan kepada pihak ketiga namun tidak termasuk antar bank) terhadap total dana pihak ketiga (mencakup giro, tabungan, dan deposito namun tidak termasuk antar bank) (Agustina, 2014). Menurut Surat Edaran OJK No. 14/SEOJK.03/2017 LDR dapat dihitung menggunakan rumus sebagai berikut:

$$
\text { LDR }=\frac{\text { Total Kredit }}{\text { Dana Pihak Ketiga }} \times 100 \%
$$

Good Corporate Governance diiukur menggunakan skor CGPI perusahaan yang diselenggarakan oleh IICG yang bekerjasama dengan Majalah SWA sebagai mitra media publikasi. Alasan menggunakan skor CGPI untuk proksi good corporate governance dikarenakan skor pemeringkatan yang dilakukan oleh IICG dapat memberikan gambaran secara langsung mengenai penerapan GCG di dalam perusahaan. Pemeringkatan CGPI di golongkan menjadi 3 kategori yaitu sangat terpercaya (85-100), terpercaya (70-84) dan cukup terpercaya (55-69).

Earnings diukur menggunakan rasio return on assetsi (ROA). Rasio ini dapat mewakili tingkat profitabilitas perbankan, karena nilai profitabilitas bank yang diukur dengan aset yang sebagian besar dananya berasal dari dana simpanan masyarakat (Anggarsini dan Suprasto, 2018). Menurut Surat Edaran OJK No. 14/SEOJK.03/2017 Return On Assets (ROA) dapat dihitung dengan rumus sebagai berikut:

$$
\text { ROA }=\frac{\text { Laba Sebelum Pajak }}{\text { Total Aset }} \times 100 \%
$$

Capital diukur dengan nilai Capital Adequacy Ratio (CAR). CAR merupakan rasio yang menunjukkan jumlah aktiva bank yang mengandung unsur risiko yang dibiayai dengan modal sendiri ataupun dari dana yang berasal dari sumber-sumber di luar bank (Utami, 2015). Berdasarkan Surat Edaran OJK No. 14/SEOJK.03/2017, rasio CAR dapat dirumuskan sebagai berikut:

$$
\text { CAR }=\frac{\text { Modal Bank }}{\text { ATMR }} \times 100 \%
$$

Seluruh perusahaan sektor perbankan yang terdaftar di Bursa Efek Indonesia Tahun 2013-2017 merupakan populasi dalam penelitian ini. Sampel 
penelitian ini adalah perusahaan sektor perbankan yang telah diseleksi menggunakan metode nonprobability sampling dengan teknik purposive sampling. Jenis data dalam penelitian ini adalahi data kuantitatif berupa nilai rasio non performing loan (NPL), loan to deposit ratio (LDR), skor CGPI, rasio return on asset (ROA), nilai capital adequecy ratio (CAR), harga saham dan nilai buku saham yang terdapat dalam annual report perusahaan perbankan selama periode 2013-2017. Sumber data penelitian ini adalah data sekunder berupa annual report perusahaan perbankan periode 2013-2017 yang dipublikasikan di website Bursa Efek Indonesia (BEI) yang diakses melalui www.idx.co.id. Metode nonparticipant observation merupakan metode pengumpulan data yang digunakan dalam penelitian ini.

Analisis regresi linear berganda merupakan teknik analisis data yang digunakan dalam penelitian ini untuk mengetahui pengaruh non performing loan (NPL), loan to deposit ratio (LDR), good corporate governance (GCG), return on asset (ROA) dan capital adequacy ratio (CAR) terhadap nilai perusahaan pada perusahaan perbankan tahun 2013-2017. Sebelum diuji dengan analisis regresi linear berganda data yang diperoleh diuji terlebih dahulu dengan menggunakan uji asumsi klasik untuk menghasilkan model regresi yang bersifat BLUE (Best Linier Unbiased Estimator). Adapun persamaan regresi yang digunakan dalam penelitian ini adalah sebagai berikut:

$$
Y=a+\beta_{1} . X_{1}+\beta_{2} . X_{2}+\beta_{3} . X_{3}+\beta_{4} . X_{4}+\beta_{5} . X_{5}+\text { e. }
$$

Keterangan :

$\mathrm{Y}=$ nilai perusahaan

$\alpha=$ konstanta

$\beta_{1-} \beta_{5}=$ koefisien regresi

$\mathrm{X}_{1}=$ non performing loani (NPL)

$\mathrm{X}_{2}=$ loan to deposit ratio (LDR)

$\mathrm{X}_{3}=$ good corporate governance (GCG)

$\mathrm{X}_{4}=$ return on assets $(\mathrm{ROA})$

$\mathrm{X}_{5}=$ capital adequecy ratio (CAR)

$\mathrm{e}=$ standard error

\section{HASIL DAN PEMBAHASAN}

Setelah melakukan seleksi pemilihan sampel dengan teknik purposive sampling, perusahaan yang memenuhi kriteria sebanyak 6 perusahaan perbankan. Seleksi sampel yang dilakukan dengan kriteria sebagai berikut:

\section{Tabel 1. Seleksi Jumlah Sampeli}

\begin{tabular}{clc}
\hline No. & Kriteriai \\
\hline 1. & Perusahaan perbankan yang terdaftar di BEI daril tahun 2013-2017 & 43 \\
2. & Perusahaan yang tidak menerbitkan annual report tahun 2013-2017 & $(9)$ \\
3. & Perusahaan perbankan yang tidak mengikuti pemeringkatan CGPI & $(28)$ \\
& Jumlah perusahaan perbankan yang memenuhi kriteria sampel & 6 \\
\hline & Jumlah pengamatan (6 perusahaan x 5 tahun) & 30 \\
\hline Sumber : Data Penelitian, 2019 & \\
& Statistik deskriptif disajikan untuk memberikan informasi mengenai \\
karakteristik variabel penelitian, seperti nilai minimum, nilai maksimum,nilai
\end{tabular}


rata-rata serta standar deviasi. Hasil statistik deskriptif setiap variabel disajikan pada Tabel 2.

Tabel 2. Hasil Statistik Deskriptif

\begin{tabular}{lrrrrr}
\hline & N & Minimum & Maximum & Mean & Std. Deviation \\
\hline PBV & 30 & 0,79 & 4,27 & 1,9967 & 1,02148 \\
NPL & 30 & 0,44 & 4,05 & 2,1037 & 0,99537 \\
LDR & 30 & 75,40 & 108,86 & 89,2943 & 9,07771 \\
GCG & 30 & 84,94 & 93,86 & 88,2703 & 2,42911 \\
ROA & 30 & 1,09 & 4,46 & 2,6639 & 0,96670 \\
CAR & 30 & 14,64 & 23,10 & 18,5823 & 2,45065 \\
Valid N (listwise) & 30 & & & & \\
\hline
\end{tabular}

Sumber : Data Penelitian, 2019

Berdasarkan Tabel 2. hasil statistik deskriptif, nilai perusahaan yang dinilai menggunakan rasio price to book value (PBV). Price to Book Value (PBV) memiliki nilai minimum sebesar 0,793 pada Bank Tabungan Negara (Persero) Tbk Tahun 2013 dan nilai maksimum sebesar 4,273 pada Bank Central Asia Tbk Tahun 2014. Nilai rata-rata (mean) price to book value sebesar 1,9967 dan standar deviasi sebesar 1,02148. Hal ini berarti rata-rata nilai perusahaan perbankan menunjukkan harga saham perbankan dinilai lebih tinggi dari harga bukunya.

Non Performing Loan $\left(\mathrm{X}_{1}\right)$ memiliki nilai minimum $0,44 \%$ sedangkan nilai maksimum sebesar $4,05 \%$. Nilai rata-rata (mean) rasio non performing loan sebesar $2,1037 \%$ artinya bank pada sampel penelitian ini telah memenuhi ketentuan dalam menjaga nilai NPL di bawah 5\% yang menunjukkan bahwa bank dalam keadaan sehat, dengan nilai standar deviasi sebesar 0,99537\%. Loan to Deposit Ratio $\left(\mathrm{X}_{2}\right)$ memiliki nilai minimum sebesar $75,40 \%$ sedangkan nilai maksimum sebesar 108,86\%. Nilai rata-rata (mean) loan to deposit ratio sebesar 89,2943\% artinya bank pada sampel penelitian termasuk kriteria bank yang cukup sehat dalam menyalurkan dana pihak ketiga dalam bentuk kredit, serta nilai standar deviasi sebesar 0,97771. Good Corporate Governance $\left(X_{3}\right)$ memiliki nilai minimum sebesar 84,94 sedangkan nilai maksimum sebesar 93,86. Nilai rata-rata (mean) skor CGPI sebesar 88,2703 artinya bank pada sampel penelitian ini sudah menerapkan GCG dengan baik dan memiliki peringkat sangat terpercaya dalam pemeringkatan CGPI, dengan nilai standar deviasi sebesar 2,42911. Return on Asset $\left(\mathrm{X}_{4}\right)$ memiliki nilai minimum sebesar 1,09\% sedangkan nilai maksimum sebesar $4,46 \%$. Nilai rata-rata (mean) return on asset sebesar $2,6639 \%$ menunjukkan bahwa perusahaan perbankan masuk sampel penelitian ini mampu memperoleh laba sebesar 2,6639\% dari total asset yang dimiliki perusahaan dalam satu periode, dengan nilai standar deviasi sebesar 0,96670\%. Capital Adequacy Ratio $\left(X_{5}\right)$ memiliki nilai minimum sebesar $14,64 \%$ sedangkan nilai maksimum sebesar $23,10 \%$. Nilai rata-rata (mean) capital adequacy ratio sebesar 18,5823\% menunjukkan bank yang termasuk dalam sampel penelitian ini mampu mencukupi kebutuhan modalnya dengan memenuhi ketentuan permodalan minimum sebesar $8 \%$, dengan nilai standar deviasi sebesar 2,45065\%.

Hasil analisis regresi linear berganda dapat dilihat pada Tabel 3 sebagai berikut: 
Tabel 3. Hasil Analisis Regresi Linear Berganda

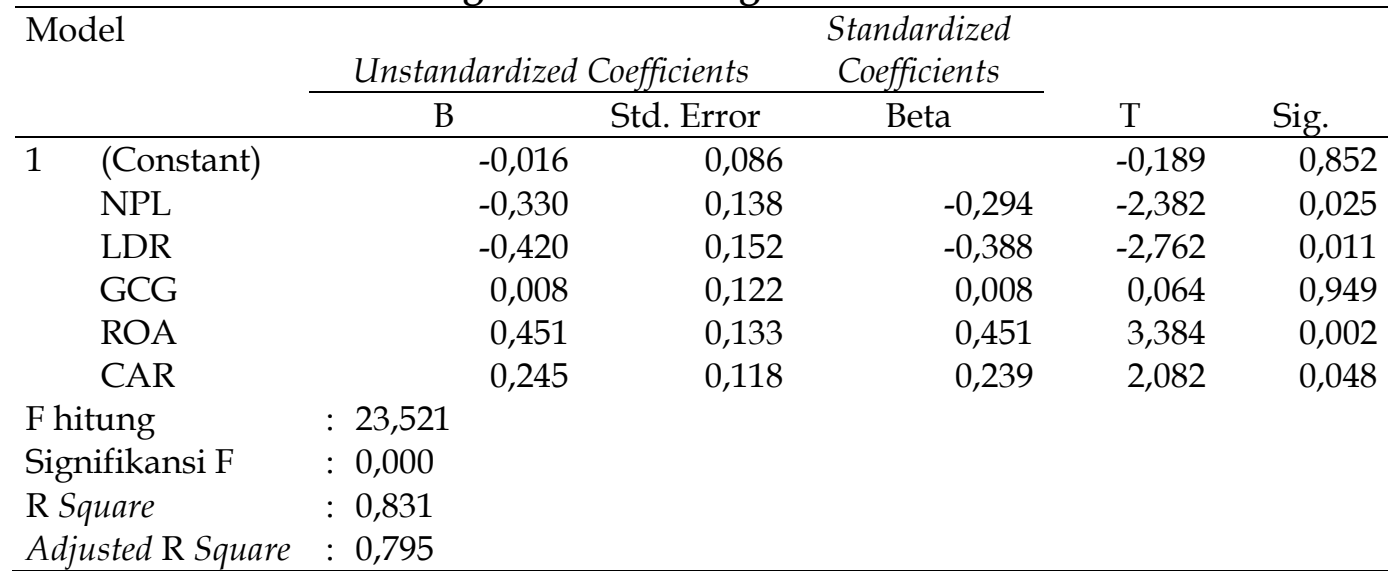

Sumber: Data Penelitian, 2019

Berdasarkan hasil analisis regresi linier berganda yang disajikan pada Tabel 3, maka dapat dibuat persamaan regresi sebagai berikut:

$$
Y=-0,016-0,330 X_{1}-0,420 X_{2}+0,008 X_{3}+0,451 X_{4}+0,245 X_{5}+e
$$

Nilai konstanta $(\alpha)$ sebesar $-0,016$ memiliki arti apabila nilai variabel independen sama dengan nol, maka variabel $Y$ bernilai sebesar $-0,016$. Nilai koefisien regresi $X_{1}=-0,330$ artinya apabila nilai non performing loan mengalami peningkatan satu persen maka nilai perusahaan akan menurun sebesar 33 persen dengan asumsi variabel independen lainnya konstan. Nilai koefisien regresi $X_{2}=-$ 0,420 artinya bila nilai loan to deposit ratio mengalami peningkatan satu persen maka nilai perusahaan akan menurun sebesar 42 persen dengan anggapan variabel independen lainnya konstan. Nilai koefisien regresi $X_{3}=0,008$ artinya bila nilai good corporate governance mengalami peningkatan satu persen maka nilai perusahaan akan bertambah sebesar 0,8 persen dengan asumsi variabel independen lainnya konstan. Nilai koefisien regresi $X_{4}=0,451$ artinya bila nilai return on asset mengalami peningkatan satu persen maka nilai perusahaan akan bertambah sebesar 45,1 persen dengan asumsi variabel independen lainnya. konstan. Nilai koefisien regresi $\mathrm{X}_{5}=0,245$ artinya bila nilai capital adequacy ratio meningkat satu persen maka nilai perusahaan akan bertambah sebesar 24,5 persen dengan anggapan variabel lainnya konstan.

Uji F dilakukan untuk mengetahui apakah model regresi layak atau tidak digunakan dalam penelitian. Hasil uji $\mathrm{F}$ ( $F$ test) menunjukkan nilai $\mathrm{F}$ hitung sebesar 23,521 dengan nilai signifikansi $P$ value 0,000 lebih kecil dari $a=0,05$, menujukkan model regresi layak digunakan pada penelitian ini. Koefisien determinasi $\left(\mathrm{R}^{2}\right)$ digunakan untuk mengetahui dan mengukur kemampuan model dalam menerangkan variasi variabel independen. Besarnya adjusted $\mathrm{R}^{2}$ (koefisien determinasi yang telah disesuaikan) adalah sebesar 0,795. Ini berarti variasi Price to Book Value (PBV) pada perusahaan perbankan selama periode 2013-2017 dapat dipengaruhi secara signifikan oleh variabel Non Performing Loan (NPL) $\left(\mathrm{X}_{1}\right)$, Loan to Deposit Ratio (LDR) $\left(\mathrm{X}_{2}\right)$, Good Corporate Governance (GCG) $\left(\mathrm{X}_{3}\right)$, Return on Assets (ROA) $\left(\mathrm{X}_{4}\right)$, dan Capital Adequacy Ratio (CAR) ( $\left.\mathrm{X}_{5}\right)$ sebesar 79,50 persen, sedangkan sisanya sebesar 20,5 persen dijelaskan oleh faktor-faktor lain yang tidak ada dalam model regresi yang digunakan. 
Berdasarkan Tabel 3. koefisien regresi NPL sebesar $-0,330$ dengan nilai signifikansi sebesar 0,025 yang lebih kecil dari tingkat signifikansi sebesar 0,05. Hasil pengujian ini menunjukkan non performing loan berpengaruh negatif dan signifikan pada nilai perusahaan perbankan yang diproksikan menggunakan price to book value (PBV), sehingga hipotesis pertama $\left(\mathrm{H}_{1}\right)$ diterima. Semakin tinggi rasio NPL, maka nilai perusahaan perbankan akan menurun. Hasil penelitian ini sejalan dengan penelitian yang dilakukan oleh Hidayat (2014), Nugroho dan Kusumawati (2017) dan Anggarsini dan Suprasto (2018) yang menemukan bahwa nontperformingt loan (NPL) berpengaruh negatif pada nilai perusahaan. Informasi mengenai rasio NPL dapat menjadi sinyal bagi investor, rasio NPL yang semakin tinggi memberikan sinyal bahwa semakin buruknya kualitas kredit bank yang menyebabkan jumlah kredit bermasalah semakin besar. Hal ini menunjukkan bank tidak mampu mengelola risiko kredit yang akan menghambat kegiatan operasional perbankan sehingga memicu terjadinya kebangkrutan, hal ini tentunya akan menurunkan kepercayaan nasabah serta investor yang akan berdampak pada penurunan harga saham yang diikuti dengan menurunnya nilai perusahaan.

Berdasarkan Tabel 3. koefisien regresi LDR sebesar -0,420 dengan nilai signifikansi sebesar 0,011 lebih kecil dari tingkat signifikansi sebesar 0,05. Hasil pengujian ini menunjukkan loan to deposit ratio berpengaruh negatif dan signifikan pada nilai perusahaan perbankan yang diproksikan dengan price to book value (PBV), sehingga hipotesis kedua $\left(\mathrm{H}_{2}\right)$ diterima. Hal ini artinya meningkatnya nilai loan to deposit ratio (LDR) maka nilai perusahaan akan mengalami penurunan. Hasil penelitian ini sejalan dengan penelitian yang dilakukan oleh Yuliati dan Zakaria (2016) yang menemukan bahwa loan to deposit ratio berpengaruh negatif pada nilai perusahaan. Perusahaan yang memiliki rasio LDR yang tinggi dapat memberi sinyal bahwa kemampuan bank dalam menyalurkan dana pihak ketiga yang dimilikinya ke dalam bentuk kredit yang diberikan semakin baik. Namun, tingginya rasio LDR akan menurunkan persentase cadangan likuiditas yang berdampak pada ketidakmampuan bank dalam menyediakan dana yang dapat ditarik sewaktu-waktu oleh para deposan, hal ini akan meningkatkan risiko likuiditas perusahaan perbankan. Meningkatnya risiko yang dimilki oleh bank tentu akan memberikan sinyal yang buruk kepada investor dan berpengaruh terhadap menurunnya kepercayaan investor ataupun masyarakat terhadap perusahaan perbankan sehingga dapat menurunkan nilai perusahaan.

Berdasarkan Tabel 3. koefisien regresi GCG sebesar -0,008 dengan nilai signifikansi sebesar 0,949 yang lebih besar dari tingkat signifikansi sebesar 0,05. Hasil pengujian ini menunjukkan good corporate governance tidak berpengaruh pada nilai perusahaan perbankan yang diproksikan dengan price to book value (PBV), sehingga hipotesis ketiga $\left(\mathrm{H}_{3}\right)$ ditolak. Hal ini berarti naik turunnya skor CGPI perusahaan tidak berpengaruh pada nilai perusahaan perbankan. Hasil penelitian ini sejalan dengan penelitian yang dilakukan oleh Sitorus et al., (2013), Fitri dan Herwiyanti (2015) dan Fatchan dan Trisnawati (2016) yang menemukan bahwa good corporate governance(GCG) tidak memiliki pengaruh pada nilai perusahaan. Perusahaan yang memiliki skor tinggi dalam pemeringkatan Corporate Governance Perception Index (CGPI) tidak mampu menjamin para 
investor memberikan respon positif terhadap hal tersebut meskipun perusahaan sektor perbankan di Indonesia telah menerapkan GCG dengan baik. Hal ini dikarenakan pasar tidak dapat secara langsung memberikan respon terhadap penerapan GCG pada suatu perusahaan melainkan respon pasar memerlukan waktu, sehingga pengaruh GCG tidak dapat diukur kesuksesannya jika hanya melihat pada satu periode akuntansi saja. Selain itu, tidak diwajibkannya seluruh perusahaan untuk mengikuti pemeringkatan CGPI di Indonesia atau dengan kata lain masih bersifat sukarela (voluntary) mengakibatkan sedikitnya perusahaan perbankan yang ikut serta dalam penilaian CGPI secara rutin setiap tahunnya. Hal ini mengakibatkan pasar kurang percaya pada hasil pemeringkatan CGPI.

Berdasarkan hasil Tabel 3. koefisien regresi ROA sebesar 0,451 dengan nilai signifikansi sebesar.0,002 lebihi kecil dari tingkat signifikansi sebesar 0,05. hasil pengujian ini menunjukkan return on asset berpengaruh positif pada nilai perusahaan perbankan yang diproksikan menggunakan price to book value (PBV), sehingga hipotesis keempat $\left(\mathrm{H}_{4}\right)$ diterima. Hal ini berarti semakin tinggi nilai return on asset maka nilai perusahaan akan meningkat. Hasil penelitian ini konsisten dengan penelitian yang dilakukan oleh Anggarsini dan Suprasto (2018), Indasari dan Yadnyana (2018) dan Irianti dan Saifi (2017) serta Kusuma dan Musaroh (2014) yang menemukan bahwa return on assets (ROA) memiliki pengaruh positif pada nilai perusahaan. Informasi tentang earnings dapat menjadi sinyal bagi pihak eksternal perusahaan yang menunjukkan bahwa manajemen telah mampu menghasilkan laba dengan pengelolaan asset perusahaan secara efisien. Selain itu, besarnya laba yang dihasilkanakan berdampak pada peningkatan pembagian keuntungan kepada para pemegang saham perusahaan (dividen). Hal tersebut tentu akan meningkatkan minat investor untuk melakukan investasi pada perusahaan tersebut sehingga harga pasar saham akan meningkat dan diikuti dengan peningkatkan nilai perusahaan.

Berdasarkan hasil Tabel 3. koefisien regresi CAR sebesar 0,245 dengan nilai signifikansi sebesar 0,048 lebih kecil dari tingkat signifikansi sebesar 5 persen $(0,05)$. Hasil pengujian ini menunjukkan capital adequacy ratio berpengaruh positif pada nilai perusahaan perbankan yang diproksikan dengan price to book value (PBV), sehingga hipotesis kelima $\left(\mathrm{H}_{5}\right)$ diterima. Meningkatnya nilai capital adequacy ratio maka nilai perusahaan akan meningkat. Hasil penelitian ini sejalan dengan penelitian yang dilakukan oleh Anggarsini dan Suprasto (2018) serta Lestari dan Wirakusuma (2018) yang menemukan bahwa capital adequacy ratio (CAR) berpengaruh positif terhadap nilai perusahaan. Tingginya nilai CAR suatu bank menjadi suatu sinyal bagi para investor yang menunjukkan semakin baiki pembiayaan atas aktiva berisiko yang dimiliki oleh bank sehingga bank mampu meminimalisir kemungkinan terjadinya kebangkrutan. Berdasarkan Peraturan OJK Nomor 11/POJK.03/2016, permodalam minimum yang harus dimiliki oleh bank adalah delapan persen. CAR menunjukkan kemampuan bank untuk menutupi risiko kerugian dari aktivitas yang dilakukan serta kesanggupan bank untuk membiayai kegiatan operasionalnya. Hal ini dapat memberikan sinyal bagi investor bahwa perusahaan dalam keadaan yang baik, sehingga investor tertarik untuk membeli saham perusahaan, hal tersebut tentunya berdampak 
pada kenaikan harga saham perusahaan yang akan diikuti dengan terjadinya peningkatan nilai perusahaan tersebut.

\section{SIMPULAN}

Berdasarkan hasil dari analisis data dan pembahasan yang telah diuraikan, maka dapat ditarik simpulan bahwa risiko kredit yang diproksikan dengan non performing loan berpengaruh negatif pada nilai perusahaan perbankan. Risiko likuiditas yang diproksikan dengan loan to deposit ratio berpengaruh negatif pada nilai perusahaan perbankan. Good corporate governance tidak berpengaruh pada nilai perusahaan perbankan. Hal ini menjelaskan bahwa semakin tinggi atau rendah good corporate governance tidak memiliki pengaruh pada nilai perusahaan perbankan. Earnings yang diproksikani dengan return on asset berpengaruh positif pada nilai perusahaan perbankan. Capital yang diproksikan dengan capital adequacy ratio berpengaruh positif pada nilai perusahaan perbankan.

Berdasarkan simpulan yang sudah diuraikan, maka saran-saran yang dapat disampaikan adalah perusahaan perbankan perlu memperhatikan dan mengelola non performing loan (NPL) dan loan to deposit ratio (LDR) karena semakin tinggi nilai NPL dan LDR maka nilai perusahaan perbankan akan menurun. Dengan cara meningkatkan pengawasan pemberian kredit agar tingkat risiko kredit dan risiko likuiditas dapat diminimalkan sehingga dapat menjaga dan meningkatkan nilai perusahaan perbankan. Hasil penelitian bagi para investor dapat digunakan sebagai bahan pertimbangan yang bermanfaat dalam mengambil keputusan berinvestasi pada suatu perusahaan, khususnya pada sektor perbankan. Bagi peneliti selanjutnya diharapkan mampu memperluas sampel penelitian dan data penelitian agar hasil lebih akurat atau menambahkan variabel lain yang berpengaruh namun tidak terdapat pada penelitian ini.

\section{REFERENSI}

Agbeja, O., Adelakun, O. J., \& Olufemi, F. I. (2015). Capital Adequacy Ratio and Bank Profitability in Nigeria: A Linear Approach. International Journal of Novel Research in Marketing Management and Economics, 2(3), 91-99.

Agustina, L. A. A. (2014). Pengaruh CAR, NPL, NIM, LDR, DAN BOPO Terhadap Nilai Perusahaan dengan ROA Sebagai Variabel Intervening pada Bank-Bank Umum Go Public di Indonesia Periode 2008-2012. Skripsi.

Alshatti, A. S. (2015). The Effect of Credit Risk Management on Financial Performance of The Jordanian Commercial Banks. Journal Investment Management and Financial Innovations, 12(1), 338-345.

Anggarsini, N. W., \& Suprasto, H. B. (2018). Pengaruh Tingkat Kesehatan Bank dan Corporate Social Responsibility pada Nilai Perusahaan Perbankan. EJurnal Akuntansi Universitas Udayana, 25(2), 1308-1338.

Asiri, B. K., \& Hameed, S. A. (2014). Financial Ratios and Firm 's Value in the Bahrain Bourse. Research Journal of Finance and Accounting, 5(7), 1-10.

Chowdhury, A., \& Chowdhury, S. P. (2010). Impact of Capital Structure on Firm 's Value: Evidence from Bangladesh. Business and Economic Horizons, 3(3), 
11-122.

Dewi, N. W. S. K., \& Yadnyana, I. K. (2019). Pengaruh Indikator Risk Based Bank Rating Terhadap Kinerja Keuangan Pada Perusahaan Perbankan yangTerdaftar di BEI Tahun 2012-2016. E-Jurnal Akuntansi Universitas Udayana, 26(2), 1075-1102.

Fama, E. F. (1978). The Effects of Firm's Invetment and Financing Decisions on the Welfare of Its Security Holders (hal. 272-284). hal. 272-284.

Fatchan, I. N., \& Trisnawati, R. (2016). Pengaruh Good Corporate Governance pada Hubungan Antara Sustainability Report dan Nilai Perusahaan. Riset Akuntansi dan Keuangan Indonesia, 1(2011), 25-34.

Fitri, R. A., \& Herwiyanti, E. (2015). Pengaruh Corporate Social Responsibility dan Good Corporate Governance Terhadap Nilai Perusahaan. Journal $\mathcal{E}$ Proceeding Fakultas Ekonomi dan Bisnis Universitas Jenderal Soedirman, 5(1), 59-75.

Fitriyanto, R. (2018). Analisis Pengaruh Liquidity Risk dan Credit Risk Terhadap Probability of Default Bank. Skripsi Mahasiswa Universitas Muhammadiyah Surakarta.

Gherghina, Ş. C. (2015). Corporate Governance Ratings and Firm Value: Empirical Evidence from the Bucharest Stock Exchange. International Journal of Economics and Financial Issues, 5(1), 97-110.

Hermuningsih, S. (2013). Profitability, Growth Opportunity, Capital Structure, and the Firm Value. Jurnal Buletin Ekonomi Moneter dan Perbankan, 16(2), 128-148.

Hidayat, M. (2014). Pengaruh Rasio Kesehatan Perbankan Terhadap Nilai Perusahaan (Studi Kasus Pada Perbankan Yang Terdaftar di Bursa Efek Indonesia). Jurnal Ekonomi dan Informasi Akuntansi (JENIUS), 4(1), 41-47.

Indasari, A. P., \& Yadnyana, I. K. (2018). Pengaruh Profitabilitas , Growth Opportunity, Likuiditas, Dan Struktur Modal Pada Nilai Perusahaan. EJurnal Akuntansi Universitas Udayana, 22(1), 714-746.

Irianti, A. S., \& Saifi, M. (2017). Pengaruh Tingkat Kesehatan Bank dengan Menggunakan Metode Risk-Based Bnk Rating Terhadap Nilai Perusahaan (Studi Pada Perusahaan Perbankan Umum Konvensional Sektor Bank Umum Swasta Devisa yang Terdaftar di BEI periode 2013-2015 ). Jurnal Admnistrasi Bisnis (JAB), 50(1), 56-64.

Jensen, M. C., \& Meckling, W. H. (1976). Theory of the firm: managerial behavioragency and ownership structure. Journal of Financial Economics, 3, 305-360. https:/ / doi.org/10.1016/0304-405X(76)90026-X

Johnson, Simon, Boone, P., Breach, A., \& Friedman, E. (2000). Corporate Governance in the Asian Financial Crisis. Journal of Financial Economics, $58,141-186$.

Kusuma, I., \& Musaroh. (2014). Pengaruh Rasio Keuangan Terhadap Nilai Perusahaan Perbankan yang Terdaftar di Bursa Efek Indonesia. E-Jurnal Universitas Negeri Yogyakarta, 3(4).

Lestari, D. M. G., \& Wirakusuma, M. G. (2018). Pengaruh Metode RGEC (Risk Profile, Good Corporate Governance, Earnings, dan Capital) Pada Nilai Perusahaan. E-Jurnal Akuntansi Universitas Udayana, 24(3), 2049-2072.

Maheswari, I. G. A. G., \& Suryanawa, I. K. (2016). Pengaruh Tingkat Kesehatan 
Bank dan Ukuran Bank Terhadap Nilai Perusahaan. E-Jurnal Akuntansi Universitas Udayana, 16(2), 1319-1346.

Moniaga, F. (2013). Struktur Modal, Profitabilitas dan Struktur Biaya Terhadap Nilai Perusahaan Industri Keramik, Porcelen dan Kaca Periode 2007-2011. Jurnal EMBA, 1(4), 433-442.

Muhammad, N., \& Scrimgeour, F. (2014). Stock Returns and Fundamentals in the Australian Market. Asian Journal of Financial \& Accounting, 6(1), 271-290. https:// doi.org/10.5296/ajfa.v6i1.5486

Nugroho, A., \& Kusumawati, R. (2017). Pengaruh Kecukupan Modal, Risiko Kredit, Profitabilitas dan Kebijakan Dividen Terhadap Nilai Perusahaan (Studi Kasus Pada Perusahaan Perbankan yang Terdaftar di BEI Periode 2012-2015). jurnal Mahasiswa Universitas Muhammadiyah Yogyakarta, 1-20.

Putra, A. (2014). The Impact of Implementation Good Corporate Governance to Firm Value (Evidence from Indonesia Public Banking sector). Review of Integrative Business $\mathcal{E}$ Economics Research, 4(1), 95-102.

Putra, I. D. A. N., \& Suardikha, I. M. S. (2018). Pengaruh Pinjaman yang Diberikan Terhadap Nilai Perusahaan dengan Non Performing Loan Sebagai Variabel Pemoderasi. E-Jurnal Akuntansi Universitas Udayana, 23(2), 1201-1224.

Ross, S. A., Westerfield, R. W., Jordan, B. D., Lim, J., \& Tan, R. (2016). Fundamental of Corporate Finance (Second). New York: McGraw-Hill Education.

Sitorus, Tigor, Sitorus, T. V. T., \& Adhiwardana, E. S. (2013). Corporate Social Responsibility as Mediating Variable on Good Corporate Governance Influences Toward Corporate Value: Empirical Study at Indonesian Government Bank Listed in Indonesian Stock Exchange 2012. Proceedings of 23rd International Business Research Conference, 1-21.

Spence, M., Quarterly, T., \& Aug, N. (1973). Job Market Signaling. The Quartely Journal of Economics, 87(3), 355-374.

Todorovic, I. (2013). Impact of Corporate Governance on Performance of Companies. Montenegrin Journal of Economics, 9(2), 47-53.

Utami, S. B. (2015). Perbandingan Analisis CAMELS dan RGEC Dalam Menilai Tingkat Kesehatan Bank Pada Unit Syariah Milik Pemerintah (Studi Kasus: PT Bank Negara Indonesia, Tbk. Tahun 2012-2013). Skripsi.

Wahyuni, F. (2018). Nilai Perusahaan, Indeks Tata Kelola Perusahaan dan Struktur Modal. Jurnal Ilmiah Akuntansi dan Bisnis, 13(2), 151-160.

Wardoyo, \& Agustini, R. M. (2015). Dampak Implementasi RGEC Terhadap Nilai Perusahaan yang Go Public di Bursa Efek Indonesia. KINERJA, 19(2), 126138.

Weston, J. F., \& Copeland, T. E. (1997). Manajemen Keuangan, Edisi Kesembilan. Jakarta: Binarupa Aksara.

Wijaya, I. P. I., \& Wirawati, N. G. P. (2019). Good Corporate Governance Sebagai Pemoderasi Pengaruh Profitabilitas dan Corporate Social Responsibility pada Nilai Perusahaan. E-Jurnal Akuntansi Universitas Udayana, 26(2), 1436-1463.

Yuliati, E., \& Zakaria. (2016). Analisis Risk, Earnings dan Capital terhadap Nilai Perusahaan pada Perusahaan Perbankan yang terdaftar di Bursa Efek Indonesia Tahun 2010-2014. Jurnal Future:Jurnal Manajemen dan Akuntansi, 
1(1), 108-124. 